\title{
HUBUNGAN PENGETAHUAN, STIGMA DAN EFEK PENGOBATAN DENGAN KEPATUHAN ORANG DENGAN HIV DAN AIDS (ODHA) TERHADAP TERAPI ANTIRETROVIRAL (ARV) DI KOTA KENDARI
}

\author{
The Relationship Between Knowledge, Stigma, Treatment Side-Effect And The \\ Commitment Of Aids And Hiv-Positive People To Undergo Antiretroval Theraphy \\ (ARV) In Kendari
}

\author{
Suharjuniatin Habibi ${ }^{1}$, Timbul Supodo ${ }^{2}$, Sunarsih $^{3}$ \\ Master Program in Public Health, School of Health Sciences Mandala Waluya Kendari
}

Suharjuniatin123@gmail.com

\section{Riwayat Artikel}

Diajukan: Agustus 2019

Diterima: Maret 2020

\section{Penulis Korespondensi:}

- Suharjuniatin Habibi

- Master Program in Public Health, School of Health Sciences Mandala Waluya Kendari

-Suharjuniatin123@gmail. com

\section{Kata Kunci:}

Efek Samping, Stigma, Terapi ARV

\begin{abstract}
ABSTRAK
Penyebaran HIV dan AIDS di seluruh dunia termasuk Indonesia berkembang sangat pesat. Prevalensi HIV di Sulawesi Tenggara terus meningkat, sementara pasien HIV yang tetap menjalani terapi antiretroviral (ARV) tidak sebanding dengan laju epidemi HIV. Terdapat beberapa kendala dalam meningkatkan kepatuhan ARV. Penelitian ini bertujuan untuk mengetahui hubungan pengetauan, stigma, dan efek pengobatan terhadap kepatuan Orang dengan HIV AIDS (ODHA) terhadap terapi anti retroviral di Kota Kendari. Penelitian ini merupakan studi crossectional. Populasi penelitian adalah seluruh orang dengan HIV dan AIDS di Kendari dengan jumlah 48 responden. Sampling dilakukan dengan metode simple random. Hasil penelitian menunjukkan bahwa nilai variabel pengetahuan $X^{2}$ hitung $\left\langle X^{2}\right.$ tabel $(4,375>3,841)$. Nilai stigma $X^{2}$ hitung $>X^{2}$ tabel $(19,139>3,841)$. Efek pengobatan $X^{2}$ hitung $>X^{2}$ tabel $(22,275>3,841)$. Kesimpulan penelitian ini pengetahuan, stigma dan efek pengobatan berhubungan dengan kepatuhan Orang dengan HIV Dan AIDS (ODHA) terhadap terapi antiretroviral (ARV) di Kota Kendari.
\end{abstract}

Kata Kunci : efek samping, stigma, terapi ARV

\section{ABSTRACT}

The spread of HIV and AIDS around the world, including Indonesia is growing very rapidly. HIV prevalence in Southeast Sulawesi continues to increase, while HIV patients who are still undergoing antiretroviral therapy (ARV) are not in line with the HIV epidemic. There are several constraints in improving the people's commitment to undergo ARV.This study aims to determine the relationship of the knowledge, stigma and the effect of treatment on the commitment of AIDS and HIV-Positive people to undergo antiretroviral therapy (ARV) in Kendari. This study is cross-sectional study. The population is those who suffer from HIV and AIDS in Kendari with a sample of 48 HIV-positive people. Sampling was done by simple random sampling.The result indicates that based on the chi-square test on knowledge variable, $\mathrm{X}^{2}$ count $\left\langle\mathrm{X}^{2}\right.$ table (4.375 $\rangle$ $3.841)$. The stigma results of chi-square test value of $X^{2}$ count $>X^{2}$ table (19.139> 3.841). And the treatment effect result of the chi-square test value of $X^{2}$ count $>X^{2}$ table $(22.275>3.841)$. The conclusion is there is 
relationship between, knowledge, stigma, treatment effect on the commitment of AIDS and HIV-Positive people to undergo the antiretroviral therapy (ARV) in Kendari.

Keywords : side effect, stigma, antiretroviral therapy

PENDAHULUAN

Acquired Immune Deficiency Syndrome (AIDS) adalah penyakit yang disebabkan oleh virus yang disebut Human Immunodeviciency Virus (HIV). Human Immunodeficiency Virus (HIV) merupakan salah satu masalah kesehatan masyarakat global. Penyebaran HIV dan AIDS di seluruh dunia termasuk Indonesia berkembang sangat pesat (UNAIDS, 2016).

Berdasarkan laporan Millennium Development Goal 6 (MDG 6), Proporsi penduduk yang terinfeksi HIV lanjut yang tercakup dalam ART pada tahun 2011 adalah 84,10 persen (24.410 ODHA) dan meningkat menjadi 88 persen pada tahun 2012 (30.663 ODHA), 93 persen pada tahun 2013 (39.418 ODHA). Kemudian meningkat kembali pada tahun 2014 menjadi menjadi 96 persen $\quad(50.400$ ODHA). Jumlah ODHA tahun 2014 yang pernah menerima pengobatan ARV sebanyak 84.030 orang $(77,76 \%)$ dari 108.060 orang yang memenuhi syarat, dari data tersebut ditemukan data jumlah orang yang masih mendapat pengobatan ARV sampai dengan bulan September 2014 adalah sebanyak 45.631 orang, berarti ada 38.399 orang yang berhenti melakukan pengobatan ARV, hal ini menunjukan angka kejadian kegagalan dalam pengobatan ARV yang tinggi (Kemenkes RI, 2014). Prevalensi HIV di Sulawesi Tenggara terus meningkat, sementara pasien HIV yang tetap menjalani terapi antiretroviral (ARV) tidak sebanding dengan laju epidemi HIV. Hingga akhir 2017 pasien HIV positif baru ditemukan berjumlah 998 orang, sementara yang sedang menjalani terapi ARV hanya 306 orang $(30,7 \%)$ (Andhika and Wirawan, 2017). Kota Kendari dan Baubau merupakan Kabupaten yang tertinggi kasus HIV dan AIDS (Profil Kesehatan Sulawesi Tenggara, 2017).

Terdapat beberapa kendala dalam meningkatkan kepatuhan ARV, seperti usia, pendidikan, pengetahuan, pengobatan, stigma, efek samping obat, putus asa dan tidak percaya akan khasiat obat (yayasan spiritia and 2017).

Keluarga (Jayadipraja, 2018) dan anakanak (Tasnim, 2018) yang hidup dengan HIV/AIDS rentan terhadap stigma dand iskriminasi, yang dapat dilihat dari berkurangnya akses kelayanan, kehilangan martabat dan meningkatnya kemiskinan dan deprivasi. Semua ini mempersulit pengendalian epidemic (Yarmaji adi wicaksono et al., 2018).

\section{METODE}

Jenis penelitian ini adalah penelitian kuantitatif, dengan pendekatan cross sectional study. Penelitian ini dilaksanakan di Wilayah Kerja Kota Kendari. Variabel dependen penelitian ini adalah kepatuhan terapi antiretroviral (ARV) sedangkan variabel independennya adalah pengetahuan, stigma dan efek samping obat.

Populasi dalam penelitian ini adalah seluruh Orang dengan HIV dan AIDS di Wilayah Kerja Kota Kendari dengan sampel sebanyak 48 Orang Dengan HIV dan AIDS (ODHA). Pengambilan sampel dilakukan secara simple random sampling.

Data dikumpulkan melalui kuesioner dan wawancara. Data di uji menggunakan Chi Square (Ismail, 2018). 


\section{HASIL DAN PEMBAHASAN \\ HASIL}

Tabel 1 Distribusi Frekuensi Pengetahuan Stigma, Efek Samping Obat dan Kepatuhan ODHA terhadap Terapi ARV di Kota Kendari

\begin{tabular}{ccc}
\hline Variabel & $\mathrm{n}$ & $\%$ \\
\hline Kepatuhan & & \\
\hline $\begin{array}{c}\text { Patuh } \\
\text { Tidak patuh }\end{array}$ & 31 & 35,4 \\
\hline Pengetahuan & & \\
\hline Cukup & 28 & 58,3 \\
Kurang & 20 & 41,7 \\
\hline Stigma & & \\
\hline Tinggi & 16 & 33,3 \\
Rendah & 32 & 66,7 \\
\hline Efek samping & & \\
\hline Ada riwayat & 31 & 64,6 \\
\hline Tidak ada & 17 & 35,4 \\
riwayat & &
\end{tabular}

Sumber : Data Primer

Tabel 1 menunjukkan bahwa dari 48 responden yang menyatakan patuh terhadap terapi antiretroviral sebanyak 31 responden $(64,6 \%)$ dan yang menyatakan tidak patuh sebanyak 17 responden $(35,4 \%)$. Pada tabel juga menunjukkan bahwa dari 48 responden yang pengetahuannya cukup sebanyak 28 responden $(58,3 \%)$ dan yang Pengetahuannya kurang sebanyak 20 responden $(41,7 \%)$. Dari 48 responden terdapat 16 responden $(33,3 \%)$ yang merasakan Stigma yang tinggi pada saat menjalani terapi antiretroviral dan yang merasakan Stigma Rendah sebanyak 32 responden $(66,7 \%)$. Selain itu Tabel 1, menunjukkan bahwa dari 48 responden terdapat 31 responden $(64,6 \%)$ yang menyatakan merasakan efek samping pada saat terapi dan yang menyatakan tidak merasakan efek samping sebesar 17 responden $(35,4 \%)$.
Tabel 2 Analisis Pengetahuan dengan Kepatuhan terhadapTerapi ARV

\begin{tabular}{|c|c|c|c|c|c|c|c|c|}
\hline \multirow{3}{*}{ No } & \multirow{3}{*}{$\begin{array}{c}\text { Pengetahua } \\
n\end{array}$} & \multicolumn{4}{|c|}{ Kepatuhan } & \multirow{2}{*}{\multicolumn{2}{|c|}{ Jumlah }} & \multirow{2}{*}{$\begin{array}{c}\text { Uji } \\
\text { Statisti } \\
\text { k }\end{array}$} \\
\hline & & \multicolumn{2}{|c|}{ Tidak } & \multicolumn{2}{|c|}{ Patuh } & & & \\
\hline & & $\mathrm{n}$ & $\%$ & $\mathrm{n}$ & $\%$ & $\mathrm{n}$ & $\%$ & $\mathrm{X}^{2} \mathrm{Hit}=$ \\
\hline 1. & Kurang & 11 & 55 & 9 & 45 & 20 & 100 & 4,375 \\
\hline 2. & Cukup & 0 & 21,4 & 22 & 78,6 & 28 & 100 & $\varphi=$ \\
\hline & Total & 17 & 35,4 & 31 & 64,6 & 22 & 100 & 0,346 \\
\hline
\end{tabular}

Sumber : Data Primer

Berdasarkan hasil uji statistik dengan menggunakan uji Chi Square pada $\alpha=5 \%$ dandf $=1$, diperoleh nilai $\mathrm{X}^{2}$ hitung $<\mathrm{X}^{2}$ tabel $(4,375>3,841)$, artinya ada hubungan yang bermakna antara pengetahuan dengan Kepatuhan terapi Antiretroviral pada Orang Dengan HIV ADS ( ODHA ) di Kota Kendari. Hasil uji keeratan hubungan menunjukkan koefisien Phi (Ф) sebesar 0,346, hal ini menunjukkan kekuatan hubungan yang lemah antara pengetahuan dengan kepatuhan terapi antiretroviral.

Tabel 3 Analisis Stigma dengan Kepatuhan ODHA terhadap Terapi ARV

\begin{tabular}{|c|c|c|c|c|c|c|c|c|}
\hline \multirow{3}{*}{ No } & \multirow{3}{*}{ Stigma } & \multicolumn{4}{|c|}{ Kepatuhan } & \multirow{2}{*}{\multicolumn{2}{|c|}{ Jumlah }} & \multirow{2}{*}{$\begin{array}{c}\text { Uji } \\
\text { Statistik }\end{array}$} \\
\hline & & \multicolumn{2}{|c|}{ Tidak } & \multicolumn{2}{|c|}{ Patuh } & & & \\
\hline & & $\mathrm{n}$ & $\%$ & $\mathrm{n}$ & $\%$ & $\mathrm{n}$ & $\%$ & \multirow{4}{*}{$\begin{array}{c}\mathrm{X}^{2} \mathrm{Hit}= \\
19,139 \\
\varphi= \\
0,678\end{array}$} \\
\hline 1. & Tinggi & $\begin{array}{l}1 \\
3\end{array}$ & $\begin{array}{l}81 \\
, 3 \\
\end{array}$ & 3 & 18,8 & 16 & 100 & \\
\hline \multirow[t]{2}{*}{2.} & Rendah & 4 & $\begin{array}{r}12 \\
, 5 \\
\end{array}$ & 28 & 87,5 & 32 & 100 & \\
\hline & & $\begin{array}{l}1 \\
7 \\
\end{array}$ & 17 & $\begin{array}{l}35 \\
, 4 \\
\end{array}$ & 31 & $\begin{array}{r}54 \\
, 5 \\
\end{array}$ & 48 & \\
\hline
\end{tabular}

Sumber : Data Primer

Hasil pengujian statistik dengan menggunakan uji Chi Square pada $\alpha=5 \%$ dan $\mathrm{df}=1$, diperoleh nilai $\mathrm{X}^{2}$ hitung $>\mathrm{X}^{2}$ tabel $(19,139>3,841)$, artinya ada hubungan yang bermakna antara stigma dengan Kepatuhan terapi Antiretroviral pada Orang Dengan HIV AIDS (ODHA) di Kota Kendari. Hasil uji keeratan hubungan 
menunjukkan koefisien Phi (Ф) sebesar 0,678 hal ini menunjukkan kekuatan hubungan yang kuat antara stigma dengan kepatuhan terapi antiretroviral.

\section{Tabel 4 Analisis Efek Samping dengan Kepatuhan ODHA terhadap Terapi ARV}

\begin{tabular}{|c|c|c|c|c|c|c|c|c|}
\hline \multirow{3}{*}{ No } & \multirow{3}{*}{$\begin{array}{c}\text { Efek } \\
\text { Samping }\end{array}$} & \multicolumn{4}{|c|}{ Kepatuhan } & \multirow{2}{*}{\multicolumn{2}{|c|}{ Jumlah }} & \multirow{3}{*}{$\begin{array}{c}\mathrm{Uji} \\
\text { Statistik }\end{array}$} \\
\hline & & \multicolumn{2}{|c|}{ Tidak } & \multicolumn{2}{|c|}{ Patuh } & & & \\
\hline & & $\mathrm{n}$ & $\%$ & $\mathrm{n}$ & $\%$ & $\mathrm{n}$ & $\%$ & \\
\hline \multirow{2}{*}{1.} & Ada & 1 & 82 , & & 17 , & & 10 & \multirow{4}{*}{$\begin{array}{c}\mathrm{X}^{2} \mathrm{Hit}= \\
22,275 \\
\varphi= \\
0,727\end{array}$} \\
\hline & riwayat & 4 & 4 & 3 & 6 & 17 & 0 & \\
\hline \multirow[t]{2}{*}{2.} & $\begin{array}{c}\text { Tidak } \\
\text { ada } \\
\text { riwayat }\end{array}$ & 3 & 9,7 & 28 & $\begin{array}{c}90 \\
3\end{array}$ & 31 & $\begin{array}{c}10 \\
0\end{array}$ & \\
\hline & & $\begin{array}{l}1 \\
7\end{array}$ & 17 & $\begin{array}{l}35 \\
4\end{array}$ & 31 & $\begin{array}{l}54 \\
, 5\end{array}$ & 48 & \\
\hline
\end{tabular}

Sumber : Data Primer

Berdasarkan hasil uji statistic dengan menggunakan uji Chi Square pada $\alpha=5 \%$ dan $\mathrm{df}=1$, diperoleh nilai $\mathrm{X}^{2}$ hitung $>X^{2}$ tabel $(22,275>3,841)$, artinya ada hubungan yang bermakna antara efek samping dengan Kepatuhan terapi Antiretroviral pada Orang Dengan HIV AIDS ( ODHA ) di Kota Kendari. Hasil uji keeratan hubungan menunjukkan koefisien Phi (Ф) sebesar 0,727 hal ini menunjukkan kekuatan hubungan yang kuat antara efek samping dengan kepatuhan terapi antiretroviral.

\section{PEMBAHASAN}

\section{Hubungan Pengetahuan dengan Kepatuhan ODHA terhadap Terapi ARV}

Hasil penelitian menunjukkan bahwa pengetahuan memiliki hubungan yang bermakna dengan kepatuhan terapi antiretroviral di Kota Kendari. Hasil penelitian yang ditemukan dalam penelitian ini bahwa minimnya pengetahuan tentang HIV dan ARV itu sangat mempengaruhi kesalahan dalam minum obat, Seperti salah satu ODHA yang mengaku salah prosedur dalam minum obat ARV, dimana ODHA tersebut pada awal-awal terapi ARV biasa terlambat minum obat sampai 2 jam atau saat merasa ingat atau butuh saja. Namun banyak ODHA yang memiliki pengetahuan tentang HIV dan ARV. Mereka memperoleh informasi awal tentang HIV dan ARV rata-rata dari media internet.

Penelitian ini sejalan dengan penelitian (Martonietal., 2013 ) yang menguji faktor yang mempengaruhi kepatuhan pasien HIV AIDS terhadap terapi antiretroviral (ARV). Temuan dalam penelitian ini membuktikan bahwa pengetahuan tentang terapi ARV merupakan faktor yang mempengaruhi kepatuhan terapi ARV.

\section{Hubungan Stigma dengan Kepatuhan ODHA terhadap Terapi ARV}

Hasil penelitian menunjukkan bahwa stigma memiliki hubungan yang bermakna dengan kepatuhan terapi antiretroviral di Kota Kendari. Dalam penelitian ini menemukan bahwa strategi komunikasi ODHA dalam menghadapi stigma dan atau diskriminasi secara umum ada dua. Pertama ODHA berusaha menutupi status HIV positifnya didepan umum. Pemilihan strategi ini disebabkan ODHA menyadari sebagian masyarakat belum memiliki pemahaman benar tentang HIV dan AIDS. Hal ini menempatkan ODHA pada posisi mendua (dua muka). Secara harfiah memainkan dua peran: panggung depan dimana status HIV dan AIDS disembunyikan dan panggung belakang dengan kenyataan bahwa dia adalah ODHA.

Dalam penelitian ini terlihat ODHA dalam berkomunikasi atau berinteraksi cenderung menutupi status HIV nya didepan umum. ODHA bersikap seolaholah menjadi seorang yang normal atau HIV negatif di masyarakat. Ada yang 
memilih diam ketika membahas tentang HIV dan AIDS ada pula yang mengalihkan pembicaraan ke topik lain ketika orang yang berkomunikasi bersamanya pada saat mereka menutupi statusnya ada beberapa ODHA yang merasa takut mengkonsumsi obat didepan teman atau dilingkungan kerja mereka karena mereka merasa nanti akan timbul pertanyaan apakah mereka sakit apa sehingga ada beberapa ODHA yang biasa melewati waktu yang seharusnya mereka konsumsi obat. Dari beberapa responden terdapat juga ODHA yang berpindah tempat terapi karena mersa tidak nyaman dengan tempat yang sebelumnya mereka merasa adanya perasaan dibeda-bedakan antara pasien lain sehingga mereka mencari tempat yang mereka merasa nyaman.

\section{Hubungan Efek Samping dengan Kepatuhan ODHA terhadap Terapi ARV}

Penelitian ini menunjukkan bahwa efek samping memiliki hubungan yang bermakna dengan kepatuhan terapi antiretroviral di Kota Kendari. Hasil yang ditemukan pada penelitian ini, bahwa efek samping pada awal terapi ARV sangat banyak dirasakan oleh ODHA di Kota Kendari adapun efek samping yang mereka rasakan yaitu merasa oleng, demam dan adanya ruam dikulit sehingga ada beberapa ODHA yang tidak mengkonsumsi obat terrsebut untuk beberapa hari dan bahkan ada yang sampai sebulan tetapi disaat mereka konsultasikan hal tersebut pada Dokter dan Konselor mereka akhirnya berusaha tetap konsumsi sampai mereka tidak pernah lagi mersasakan efek tersebut.

Peneliti Okki Ramadian (2010), menemukan bahwa pengaruh efek samping ARV tahap pertama terhadap kepatuhan ARV pada 137 ODHA di layanan terpadu HIV Rumah Sakit Cipto Mangunkusumo (RSCM) berdasarkan analisis statistik secara bivariat memberikan gambaran bahwa ada hubungan yang signifikan antara efek samping pengobatan ARV tahap pertama dengan tingkat kepatuhan.

\section{KESIMPULAN}

Simpulan dari penelitian ini adalah ada hubungan pengetahuan, stigma dan efek samping dengan kepatuhan ODHA terhadap terapi ARV di Kota Kendari. Diharapkan tidak ada tindakan diskriminasi pada Orang Dengan HIV dan AIDS (ODHA) dan khususnya ODHA dapat mengetahui pentingnya Terapi antiretroviral.

\section{DAFTAR PUSTAKA}

Profil Kesehatan Sulawesi Tenggara 2017. Profil Kesehatan Provinsi Sulawesi Tenggara. Kendari: Dinas Kesehatan Sulawesi Tenggara

UNAIDS. 2016. Global Factsheets 2015 [Online]. UNAIDS. Available: http://aidsinfo.unaids.org//.

Kemenkes RI 2013. Laporan situasi perkembangan HIV \& AIDS diindonesia tahun 2013, Jakarta. In: PENYEHATAN, D. J. P. P. (ed.). Kementerian Kesehatan RI.

Kemenkes RI. 2014. Situasi dan analisis HIV AIDS Pusat Data dan Informasi Kementerian Kesehatan RI [Online]. Kementerian Kesehatan RI. Available: $<<$ http://www.depkes.go.id/recourc es/download/pusdatin/infodatin $\% 20$ AIDS.pdf.

Jayadipraja, E. A., Prasetya, F., Azlimin, A. \&Mando, W. O. S. Y. 2018. Family Clean And Healthy Living Behavior And Its Determinant Factors In The Village Of Labunia, Regency Of Muna, Southeast Sulawesi Province Of Indonesia. Public Health of Indonesia, 4, 3945.

Tasnim, T. 2018. Determinants of Malnutrition in Children Under 
Five Years in Developing Countries: A Systematic Review. Indian Journal of Public Health Research \& Development, 9.

Yarmaji Adi Wicaksono, Alifiti Fitrikasari, Muchlis Achsan Udji Sofro \& Feni, H. 2018. hubungan stigma dan terapi ARV dengan komplikasi ganguan psikiatri pada pasien HIV/AIDS. Jurnal Penyakit dalam Indonesia, Vol 5.

Yayasan Spiritia \& 2017. Statistik Kasus HIV/AIDS di Indonesia [Online]. Available:

http://www.spiritia.or.id/stats/statist ik.php. .

Ismail, H. F. 2018. Statistika Untuk Penelitian Pendidikan dan IlmuIlmu Sosial, Kencana.
Martoni, W., Arifin, H. \& Raveinal, R. 2013. Faktor-Faktor Yang Mempengaruhi Kepatuhan Pasien HIV/AIDS di Poliklinik Khusus Rawat Jalan Bagian Penyakit Dalam RSUP dr. M. Djamil Padang Periode Desember 2011-Maret 2012. Jurnal Farmasi Andalas, 1.

Ramadian, O. \& Riztriawan, E. 2010. Pengaruh efek samping antiretroviral lini pertama terhadap adherens pada ODHA di layanan terpadu HIV RSCM. Laporan Penelitian: Kelompok Studi Khusus HIV/AIDS Rumah Sakit Cipto Mangunkusumo. Jakarta. 